${ }^{\circ}$ Entomologica Fennica. 13 November 2000

\title{
Mites (Acari: Prostigmata: Erythraeidae, Trombidiidae) new to the fauna of Norway, Finland, Russia, Latvia and Lithuania, with a descrip- tion of Podothrombium roarin. sp.
}

\author{
Ryszard Haitlinger
}

Haitlinger, R. 2000: Mites (Acari: Prostigmata: Erythraeidae, Trombidiidae) new to the fauna of Norway, Finland, Russia, Latvia and Lithuania, with a description of Podothrombium roari n. sp. — Entomol. Fennica 11: 187-193.

Podothrombium roari n. sp. is described from Middle Norway and Lithuania. Erythraeus gertrudae, Leptus mariae, L. beroni, Abrolophus brevicollis and Hauptmannia wratislaviensis are new to the fauna of Norway; Erythraeus monikae, Charletonia cardinalis and A. brevicollis are new to the fauna of Finland; Podothrombium kordulae and $H$. wratislaviensis are new to the fauna of Russia; Trombidium holosericeum and Leptus echinopus are new to the fauna of Latvia, $T$. holosericeum, A. brevicollis and $H$. wratislaviensis are new to the fauna of Lithuania. A key to Podothrombium larvae is provided.

Ryszard Haitlinger, Department of Zoology, Agricultural Academy, 50-205 Wroclaw,Cybulskiego 20, Poland; e-mail rhait@ozi.ar.wroc.pl

Received 1 December 1998, accepted 17 November 1999

In North Europe and some countries of Central Europe, Erythraeidae and Trombidiidae are poorly known. Erythraeid species, based on larvae, were recorded in Sweden and Iceland. Southcott (1992) described Leptus laplandicus from Swedish Lappland. L. beroni Fain (syn. L. holmiae Southcott) described from Belgium (Fain 1991), is known in North Europe from Iceland and Sweden and $L$. ignotus (Oudemans) was stated in Sweden. Hauptmannia wratislaviensis Haitlinger was recorded in Iceland as Balaustioides tuxeni Southcott (Southcott 1989). In this region of Europe also are known species belonging to the genera Trombidium Fabricius, Allothrombium Berlese and $\mathrm{Po}$ dothrombium Berlese, but all based on adults. For example, in Norway were stated four species of Podothrombium and in Finland Allothrombium fuliginosum (Hermann) (Makol, 1998a). Uniden- tified Podothrombium larvae have been reported from Iceland by Sellnick (1940).

In June and July 1998 several dozen erythraeid and trombidiid larvae were collected in Norway, Finland, northwestern Russia, Latvia and Lithuania. This paper described Podothrombium roari $\mathrm{n}$. sp. from Norway and Lithuania. Moreover, five new species for the fauna of Norway, three new for Finland, two new for Russia, one new for Latvia and two new for Lithuania are presented.

The new species is deposited in the Museum of Natural History, Wroclaw University (MNHWU). All measurements are given in micrometers $(\mu \mathrm{m})$.

Family Trombidiidae Leach, 1815

Subfamily Podothrombiinae Thor, 1935

Genus Podothrombium Berlese, 1910 


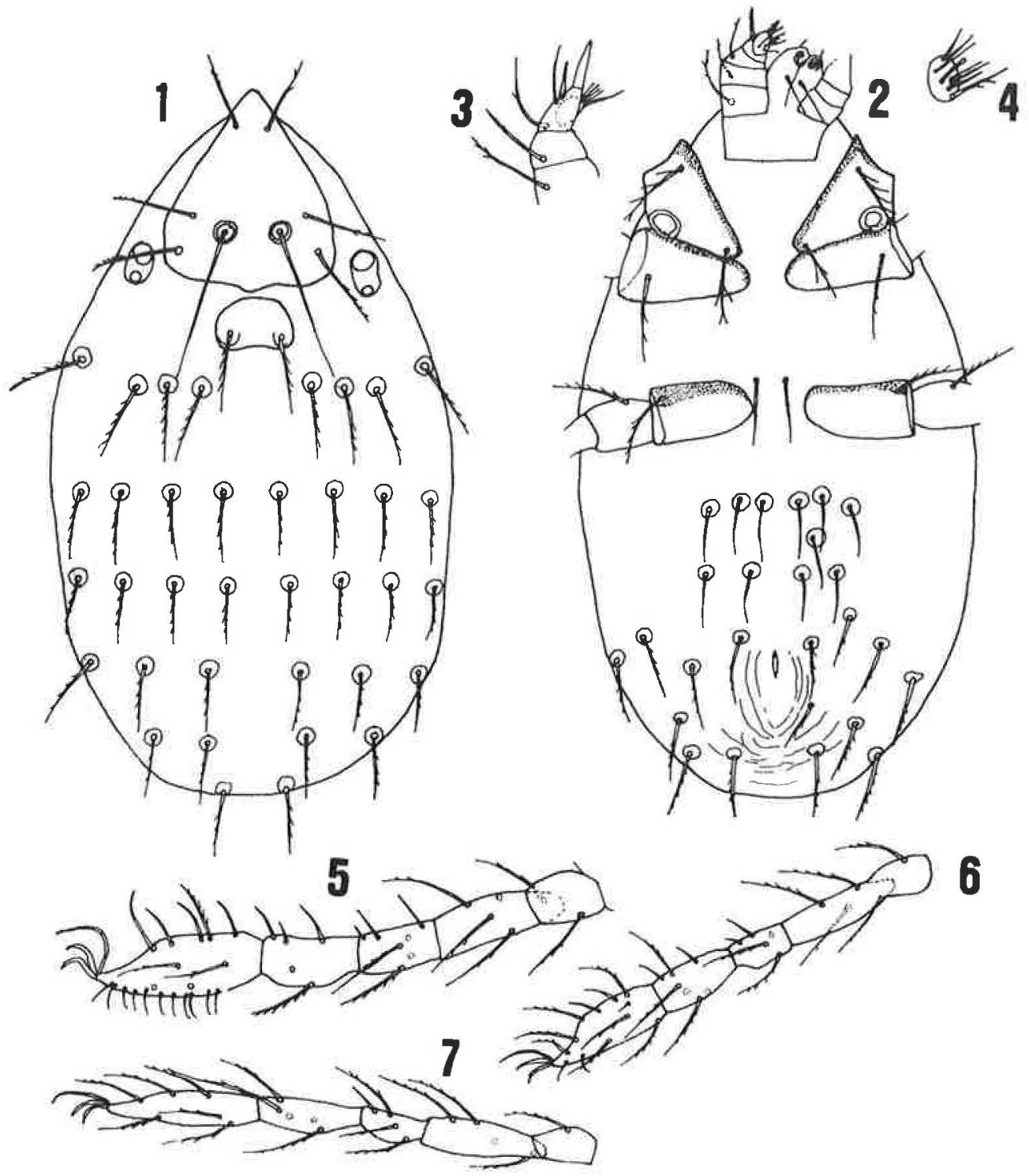

Figs. 1-5. Podothrombium roari sp. n.: 1: Idiosoma, dorsal view; 2. Idiosoma, ventral view; 3. Palp, dorsal view; 4. Palptarsus; 5. Leg I, tarsus-trochanter; 6. Leg II, tarsus-trochanter; 7. Leg III, tarsus-trochanter.

Podothrombium roari sp. n. Figs. 1-7.

Type material. Holotype larva - Norway, Trondheim, 6 July 1998. Leg. R. Haitlinger. - Paratypes - 5 LL, Malvik n. Trondheim, 6 July 1998; Lithuania, Trokai, 2 LL, 22 June 1998, Vilnius, 1 L, 22 June 1998; leg. R. Haitlinger. All larvae obtained from herbaceous plants on the brink of forest or scrubs.

Diagnosis. Larva with the following features: $\mathrm{fD}=36(34-36) ; \mathrm{fV}=26(26-28) ; \mathrm{fSol}=\mathrm{I} 0-2-2-3$, II 0-1-2-2, III 0-1-0-0; fk = I 1-0, II 1-0; f $\varepsilon$ (famu- lus) $0-1-0 ;$ f $\zeta=$ I 12 (9-12), II 2 (1-2), III 0; TaI 120 (112-124), TaIII $110(100-114) ;$ IP $=1352$ $(472+412+468)$.

Description of holotype. Larva. Idiosoma dorsally with a scutum, a scutellum, a pair of ocular sclerites, and 36 dorsal setae. Scutum triangular in shape, with posterior border slightly convex. $\mathrm{AL}$ and PL setae with minute barbs; ALlittle longer than PL (in one paratype are equal); AM setae also slightly barbed, equal in length with $\mathrm{AL}$ (in 
paratypes are longer or shorter). Setae S smooth, situated between AL and PL setae. Scutellum with anterior border slightly convex and posterior border slightly concave bearing two barbed setae (Fig 1). Dorsal setae all barbed, each arising from a small setal sclerite, arranged as follows: 8-8-8-64-2. Ocular sclerite with two eyes, the anterior eye (14 in diameter) larger than the posterior one (8 in diameter).

Idiosoma ventrally with two nude setae at coxae III and 26 setae beyond coxae III arranged as follows: 6-1-4-8-3-4. Most of setae arranged in the first row nude; setae situated in two first rows shorter and thinner than setae placed in posterior rows; all barbed. Anal opening present. Coxa I with two barbed setae, coxa II with one slightly barbed seta, coxa III with one barbed seta. Ventral setae each with a small setal sclerite (Fig. 2).

Gnathosoma with pair of subcapitular nude setae present. Palpal setal formula $\mathrm{fPp}=0-1-1$ $\mathrm{B}, \mathrm{N}, \mathrm{N}-\omega, 1 \mathrm{~B}, 6 \mathrm{~N}$. Palpfemorala slightly barbed, 38 long, palpgenuala slightly barbed, 26 long (Fig. 3). Palptarsus as in Fig. 4.

Standard measurements. IL (idiosoma length) 546 (527-743), IW (idiosoma width) 298 (330514), L 156 (140-160), W 124 (114-130), AW 84 (80-86), PW 106 (98-112), AA 24 (24-30), AP 24 (26-30), MA 72 (70-78), LN 32 (28-38), ASB 114 (98-122), PSB 42 (34-44), AM 60 (?50-72), AL 60 (56-68), PL 64 (66-72), S 120 (102-128), SB 42 (40-46), DS 46-60 (48-68), Oc (ocular plate) 36 (36-44), GL (length of gnathosoma measured between base and tip of rostrum) 84 (8496), LSS 56 (48-56), HS 42 (32-36), SL 56 (5662 , SS 42 (36-42), TaI 120 (112-124), TiI 70 (7074), GeI 52 (52-56), FeI 94 (92-112), TrI 50 (5054), CxI 86 (82-92), TaII 92 (90-104), TiII 64 (6068), GeII 42 (40-46), FeII 82 (76-90), TrII 42 (4450), CxII 90 (86-94), TaIII 110 (100-114), GeIII 48 (46-50), FeIII 94 (92-104), TrIII 54 (52-56), CxIII 86 (84-92). Index TiIII/AW 0.90 (0.86-0.97)

Leg I. The setae formula: TaI $3 \omega, 12 \zeta(9-12)$, 23B (23-33 paratypes); Ti $2 \phi, 1 \kappa, 5 B$; Ge $2 \delta, 1 \kappa$, 4B; Fe 5B, Tr 1B (Fig. 5).

Leg II. TaI $2 \omega, 1 \varepsilon, 2 \zeta(1-2), 17 \mathrm{~B}(18-21)$, TiI $2 \phi, 5 \mathrm{~B}, \mathrm{GeI} 1 \delta, 1 \kappa, 3 \mathrm{~B}, \mathrm{Fe} 4 \mathrm{~B}, \operatorname{Tr} 1 \mathrm{~B}$ (Fig. 6).

Leg III. TaI $\sim 18 \mathrm{~B}(18-20)$, Ti 5B, Ge 18, 3B, Fe 4B, Tr 1B (Fig. 7). Ip=472+412+468=1352.

Etymology. The name of the species has been derived from the name Roar.
Remarks. The new species is similar to $P$. paucisetarum Zhang \& Xin and $P$. prot $i$ Haitlinger. It differs from all Podothrombium species by the presence of three solenidia on tarsus I and furthermore from $P$. proti by shorter TiI (70-74 to $76-82)$, Till (60-68 to $66-76)$, TilII $74-80$ to $82-$ $86)$ and lower index TilIV/AW (0.86-0.97 to 0.97 1.13); from P. paucisetarum by Ip (1352 to 1459).

\section{Podothrombium kordulae Haitlinger 1995}

Material. Russia: Peterhof n. Sankt Petersburg, 10 LL, 28 June 1998, Sankt Petersburg-Olgino, 18 LL, 27 June 1998; all specimens from plants on wet meadows; leg. R. Haitlinger.

P. kordulae is known only from Lower Silesia in Poland and from one locality in East Germany (n. Görlitz) (Haitlinger 1995, M'kol 1998b). Species probably associated with wet meadows in non-wooded areas. New to fauna of Russia.

Key to species of the genus Podothrombium (larvae)

1. NDV $>110$, idiosoma dorsally with more than 70 setae

- NDV < 105, idiosoma dorsally with less than 70 setae 3

2. Idiosoma ventrally with more than 52 setae beyond coxae III; first row of dorsal setae with 18 setae arranged irregularly; scutum $148 \mathrm{~mm}$ long

........... P. piriformis Robaux; Switzerland

- Idiosoma ventrally with less than 50 setae beyond coxae III; first row of dorsal setae with about 22 setae arranged irregularly; scutum $200 \mathrm{~mm}$ long P. svalbardense Oudemans; Svalbard

3. Tarsus I longer than $190 \mathrm{~mm}$..................... 4

- Tarsus I shorter than $180 \mathrm{~mm}$..................... 5

4. First row of dorsal setae with 8 setae, tarsus I shorter than $220 \mathrm{~mm}$; ratio TaIII/AW $<2.20$ (1.80)

P. dariae Haitlinger; Poland

- First row of dorsal setae with 16 setae irregular arranged; tarsus longer than $220 \mathrm{~mm}$; ratio TaIII/AW > $2.40(2.80)$.

P. shellhammeri Robaux; USA: California

5. Tarsus I with three solenidia P. roari $n$. sp.; Norway, Lithuania

— Tarsus I with one or two solenidia ............. 6

6. Genu I with three solenidia 
P. rigobertae Haitlinger; Poland

- Genu I with less than three solenidia ....... 7

7. First row of dorsal setae with $8-10$ setae distinctly separated from the second row ...... 8

- First row of dorsal setae with other number of setae or formed in irregularly row, with more than 10 setae 13

8. Tarsus III longer than $148 \mu \mathrm{m}$ P. tymoni Haitlinger; Austria, Poland

- Tarsus III shorter than $146 \mu \mathrm{m}$ .... 9

9. Tarsi I and III longer than $125 \mu \mathrm{m}$......... 10

- Tarsi I and III shorter than $125 \mu \mathrm{m}$......... 11

10. First row of dorsal setae with 10 setae, tarsus I with famulus $(\varepsilon)$ placed far from solenidion ............ P. verae Haitlinger; Poland

- First row of dorsal setae with 8 setae, tarsus I with famulus $(\varepsilon)$ placed on the same level as solenidion

P. tersonderi Haitlinger; Poland

11. Idiosoma dorsally with less than 40 setae, NDV $<70$ setae, tarsi I,II with two solenidia each .......... P. proti Haitlinger; Italy, Poland

- Idiosoma dorsally with more than 40 setae, NDV $>70$ setae, tarsi I,II with one solenidion each 12

12. Tarsus I with 15 normal setae, tarsus I 108$120 \mu \mathrm{m}$ long

P. paucisetarum Zhang \& Xin; China

- Tarsus I with 32-33 normal setae, tarsus I 126-137 $\mu \mathrm{m}$ long ... P. sylvicolum Zhang \& Jensen; USA: Oregon

13. First dorsal row with four setae, sometimes badly separated from the second row; then forming irregular row with 16-22 setae; tarsus $\mathrm{III}>90 \mu \mathrm{m}$, ratio $\mathrm{TaI} / \mathrm{TaIII}<1.15$

P. kordulae Haitlinger; Poland, Germany, Russia

- First dorsal row with 10 setae, badly separated from the second row and then forming irregular row with 16-22 setae; tarsus $\mathrm{III}<90$ $\mu \mathrm{m}$, ratio TaI/TaIII $>1.40(1.60) \mu \mathrm{m}$ $P$. crassicristatum Feider; Romania

Subfamily Allothrombiinae Thor 1935

Genus Allothrombium Berlese 1903

\section{Allothrombium fuliginosum (Hermann 1804)}

Material. Norway: Lillehammer, 1 L, 7 July 1998, from plants on meadow; leg. R. Haitlinger. Adults were mentioned from Norway by Thor (1900) and Mehl (1979).
Subfamily Trombidiinae Leach 1815

Genus Trombidium Fabricius 1775

Trombidium holosericeum (Linnaeus 1758)

Material. Norway: Heskestad n. Egersund, 4 LL, 8 July 1998, Eimet, 1 L, 9 July 1998; Russia: Peterhof n. Sankt Petersburg 1 L, 28 June 1998; Lithuania: Vilnius, 9 LL, 22 June 1998, Kaunas 1 L, 24 June 1998; all larvae from plants on meadows; Latvia: Riga, 2 LL, 26 June 1998, from undetermined Lauxaniidae and Anthomyzidae (Diptera); leg. R. Haitlinger, det. Dr. T. Zatwarnicki. New to fauna of Latvia and Lithuania.

T. holosericeum is known (adults) from Europe and Asia. Association between larvae and their host unknown. Probably associated with various Diptera.

Family Erythraeidae Robineau-Desvoidy 1828 Subfamily Leptinae Billberg 1820 (sensu Southcott 1961)

Genus Leptus Latreille 1796

\section{Leptus mariae Haitlinger 1987 syn. L. gabrysi Southcott 1992}

Material. Norway: Heskestad n. Egersund, 2 LL, 8 July 1998 , from plants on meadows; leg. R. Haitlinger.

Species known from Poland, Slovenia, Holland, Belgium, Hungary (as L. gabrysi) and Italy (Haitlinger 1987a, 1996, 1998, Southcott 1992, Fain et al. 1992, Gabrys \& Makol 1996). New to fauna of Norway.

Larvae frequently obtainable from plants, but also on various hosts: Phyllobius urticae (De Geer) (Coleoptera: Curculionidae) and Lochmaea caprae (L.) (Chrysomelidae) both in Poland, Lagria hirta L. (Lagriidae) in Slovenia and Belgium, Dryobius roboris (L.) (Aphidoidea) in Holland, Cicadetta montana Scopoli (Homoptera: Cicadidae) in Belgium and undetermined Tenebrionidae in Italy (Gabrys 1991, Haitlinger 1991, 1998, Southcott 1992, Fain 1992, Fain et al. 1992, Fain \& Baugnée 1996). L. mariae has wide circle of hosts.

\section{Leptus beroni Fain 1991 syn. L. holmiae South- cott 1992}

Material. Norway: Heskestad n. Egersund, 3 LL, 8 July 1998, from undetermined Opiliones; leg. R. Haitlinger. 
Species widely distributed in Europe; known from Bulgaria, Poland, Ireland, United Kingdom, Denmark, Iceland, Hungary, Sweden, Russia (Bashkiria) and Belgium (Beron 1975, Haitlinger 1987a, Fain 1991, Southcott 1992, Gabryœ \& M'kol 1996). New to fauna of Norway.

L. beroni is associated especially with various Opiliones; it was obtained on Phalangium opilio (L.), Rilaena (=Platybunus) triangularis (Herbst), Lophopilio (=Odiellus) palpinalis (Herbst), Mitopus morio (F.), M. ruzikai Silh., Oligolophus tridens (C.L. Koch); moreover, was collected on Heamatopota pluvialis (L.) (Diptera: Tabanidae), Ematurga amatoria L. (Lepidoptera), undetermined Aphididae (Homoptera), and twice on Clethrionomys glareolus Schreb. (Rodentia) (Haitlinger 1991, Fain 1991, Southcott 1992).

\section{Leptus echinopus Beron 1975}

Material. Latvia: Lilaste n. Riga, 1 L, 26 June 1998, from plants on meadows; leg. R. Haitlinger.

Species known only from Bulgaria, Poland, Hungary and Denmark (Beron 1975, Haitlinger 1987a, Gabrys \& Makol 1991, Southcott 1992). New to fauna of Latvia.

L. echinopus is associated with various hosts; it was obtained on undetermined Collembola, Boletophagus reticulatus (L.) (Tenebrionidae) and adult Erythraeus sp. (Erythraeidae) (Beron 1975, Haitlinger 1991, Southcott 1992). L. echinopus was twice collected on adults in Poland and Denmark on adult Erythraeus sp.; it may suggest that some Erythraeus species (adult stage) are nonaccidental host for $L$. echinopus.

Subfamily Erythraeinae Robineau-Desvoidy 1828 Genus Erythraeus Latreille 1806

\section{Erythraeus monikae Haitlinger 1987}

Material. Finland: Oulu, 2 LL, 2 July 1998, from plants in scrubs; leg. R. Haitlinger.

Species known only from Poland (Haitlinger 1987b). New to fauna of Finland.

\section{Erythraeus gertrudae Haitlinger 1987}

Material. Norway: Heskestad n. Egersund 7 LL, Sandmark n. Heskestad I L, all specimens 8 July 1998, from plants on meadows; leg. R. Haitlinger.
Species known only from Poland (Haitlinger 1987b). New to fauna of Norway.

Subfamily Callidosomatinae Southcott 1957

Genus Charletonia Oudemans 1910

Charletonia cardinalis (C.L. Koch 1837) syn. C. singularis (Oudemans 1910)

Material. Finland: Pyhäsalmi, 1 L, 2 July 1998, from plants on meadows; leg. R. Haitlinger.

Species known from Russia, Holland, Poland, Sweden, USA (Southcott 1966, 1991, Haitlinger 1985). New to fauna of Finland.

C. cardinalis is associated with various insects, especially Cercopidae (Hemiptera) and Delphacidae (Homoptera); also was obtained from Lithina chlorosata (Scopoli) (Lepidoptera: Geometridae) Phyllotreta undulata Kutschera (Chrysomelidae) and Mustela erminea L. (Carnivora: Mustelidae) (Haitlinger 1985, 1987a, Southcott 1991).

Genus Abrolophus Berlese 1891

\section{Abrolophus brevicollis (Oudemans 1912)}

Material. Norway: Sandmark n. Heskestad, 1 L, 8 July 1998; Lillehammer, 2 LL, 7 July 1998, all specimens from plants on meadows; Malvik n. Trondheim, $1 \mathrm{~L}$ July 1998, from herbaceous plants on the brink of forest; Finland: Vehkalahti n. Kotka, 2 LL, 30 June 1998, from Belothrips sp. (Thysanoptera); Russia: Peterhof n. Sankt Petersburg, 4 LL, 28 June 1998, Sankt Petersburg-Olgino, 23 LL from plants on meadows, 5 LL from Taeniothrips sp. (Thysanoptera), (det. Dr. Z. Klukowski), 27 June 1998, Torfianovka n. Vaalimaa, 4 LL, 29 June 1998; Lithuania: Kaunas, 2 LL, 24 June 1998, Kelme n. iauliai, $4 \mathrm{LL}$ all from plants on meadows, $1 \mathrm{~L}$ from undetermined larva of Homoptera, 25 June 1998, iauliai, 6 LL, 25 June 1998, from plants on meadows; leg. R. Haitlinger.

Species known from Holland, Poland, Sweden (Sellnick 1958, Haitlinger 1986). New to fauna of Norway, Finland, Russia and Lithuania. It is associated with various Thysanoptera; rarely found on Homoptera.

Genus Hauptmannia Oudemans 1910

\section{Hauptmannia wratislaviensis Haitlinger 1986 syn. Balaustioides tuxeni Southcott 1989}

Material. Norway: Heskestad n. Egersund, 3 LL, 8 July 1998; Russia: Peterhof n. Sankt Petersburg, 2 LL, 28 
June 1998, Puฟkino n. Sankt Petersburg, 1 L, 29 June 1998; Lithuania: Kelme n. iauliai, 1 L, 25 June 1998; all specimens from plants on meadows; leg. R. Haitlinger.

Species known from Poland, Iceland (as $B$. tuxeni) and Switzerland (Haitlinger 1986, 1994, Southcott 1989). Hosts unknown. New to fauna of Norway, Russia and Lithuania.

\section{Discussion}

Erythraeid and trombidiid larvae parastize various arthropods. Nymphs and adults are predators. Because the distribution, life cycle, hosts and food spectra of most of the species remain unknown it seems advisable to report on any data which refer to these problems. Therefore, is "dual systematics" which exists separately for larvae and adults. Both the larvae and postlarval forms of Erythraeidae and Trombidiidae have good taxonomic character and are described independently.

Species mentioned in this paper belong to the genera known only from larval stages or larval and postlarval forms. Genera Hauptmannia and Charletonia are based only on larvae. But according to Welbourn \& Young (1987) Hauptmannia larvae without comb-like setae on the palptibia and a hook-like projection on the palpfemur belongs to the genus Abrolophus. Zhang \& Goldarazena (1996) accepted it and described $A$. neobrevicollis Zhang \& Goldarazena. Therefore, some larvae from Norway, Finland, Russia and Lithuania are includes to Abrolophus. Status of the genus Hauptmannia is not clear and it needs revision.

Species belonging to genera Trombidium, $A l$ lothrombium, Podothrombium, Abrolophus, Leptus and Erythraeus are known from both stages (separately). Only Trombidium holosericeum (Linnaeus) and A. fuliginosum are known from all stages. The remaining species mentioned in the paper are known only from larvae. Test of culture of larvae from determined adults is most without result.

Acknowledgement. The author is very grateful to Dr. T. Zatwarnicki and Dr. Z. Klukowski for the identification of specimens of Diptera and Thysanoptera.

\section{References}

Beron, P. 1975: Erythraeidae (Acariformes) larvaires de Bulgarie. - Acta zool. bulg. 1: 45-75.

Fain, A. 1991: Two new larvae of the genus Leptus Latreille, 1796 (Acari, Erythraeidae) from Belgium. - Internat. J. Acarol. 17 (2): 107-111.

Fain, A. \& Baugnée, J. Y. 1996: Acariens phorétiques ou parasites récoltés sur des insectes du sud de la Belgique.Deuxiéme note. - Bull. Annls Soc. r. belge Ent. 132: 19-33.

Fain, A., Baugnée, J. Y. \& Hidvegi, F. 1992: Acariens phorétiques ouparasites récoltés sur des Hyménoptéres et un Homoptére dans la région de Treignes, en Belgique. - Bull. Annls Soc. r. belge Ent. 128: 335-338.

Gabrys, G. 1991: New data on the distribution and hosts of larvae of Erythraeidae (Acari, Actinedida) in Poland. Wiad. Parazyt. 37 (1): 103-105.

Gabrys, G. \& Makol, J. 1991: Parasitengona Terrestria: Calyptostomatoidea, Erythraeoidea and Trombidioidea (Acari) of the Bátorliget Nature Reserves (NE Hungary). - In: Mahunka, S. (ed.): The Bátorliget Nature Reserves - after forty years, 1990. The Hungarian Natural History Museum, Budapest, 707-713.

Gabrys, G. \& Makol, J. 1996: Terrestrial Parasitengona (Acari) of the Bükk National Park (NE Hungary). - In: Mahunka S. (ed.): The fauna of the Bükk National Park. vol II, Hungarian Natural History Museum, Budapest, 1996: 487-490.

Haitlinger, R. 1985: Charletonia singularis (Oudemans, 1910) i inne rzadkie roztocze (Acarina) zebrane na ssakach w Polsce. - Pol. Pismo Ent. 55 (2): 433436.

Haitlinger, R. 1986: The genus Hauptmannia Oudemans, 1910 (Acari, Prostigmata, Erythraeidae) in Poland. - Pol. Pismo Ent. 56 (1): 181-191.

Haitlinger, R. 1987a: The genus Leptus Latreille, 1796 and Charletonia Oudemans, 1910 (Acari, Prostigmata, Erythraeidae)in Poland. - Pol. Pismo Ent. 57: 339-349.

Haitlinger, R. 1987b: Dalsze informacje o wystêpowaniu gatunków rodzaju Hauptmannia Oudemans, 1910 (Acari, Prostigmata, Erythraeidae) w Polsce. - Przegl. Zool. 31: 159-164.

Haitlinger, R. 1991: New data on distribution of larvae from the genus Leptus Latreille, 1796 (Acari, Prostigmata, Erythraeidae) in Poland with the description of Leptus miromiri n. sp. — Wiad. Parazyt. 37 (4): 499506.

Haitlinger, R. 1994: Two new larval mites (Acari: Trombidiidae, Erythraeidae) from Switzerland. - Mitt. Schweiz. Ent. Gesell. 67 (3/4): 405-410.

Haitlinger, R. 1996: New larval mite species of the genus Podothrombium Berlese, 1919 (Acari, Prostigmata, Trombidiidae) and Lassenia Newell, 1957 (Prostigmata, Tanaupodidae) from Poland. - Wiad. Parazyt. 41 (4): 463-474.

Haitlinger, R. 1998: Five new species of Leptus Latreille, 1796 (Acari: Prostigmata, Erythraeidae) from Asia and Africa. - Bonn. zool. Beitr. 48 (1): 97-110.

Makol, J. 1998a: Trombidiidae (Acari: Actinedida, Trombidioidea) Polski. -- Dissertation, pp. 1-313 
(unpublished).

Makol, J. 1998b: Trombidiidae (Acari, Actinedida, Trombidioidea) of the Neisse Valley and vicinity (Saxony, SE Germany). - Abh. Naturkundemus. Görlitz 70 (1): 21-27.

Mehl, R. 1979: Checklist of Norwegian ticks and mites (Acari). - Fauna Norv., s. B, 26: 31-45.

Sellnick, M. 1940: Die Milbenfauna Islands. - Göteb. Kungl. Vetens. Vitt.-Samh. Handl, s.B 6 (14): 1-121.

Sellnick, M. 1958: Milben aus landwirtschäftlichen Betrieben Nordschwedens. - Medd. Växtskyddsanst. Stock. 11 (71-72): 9-59.

Southcott, R. V. 1966: Revision of the genus Charletonia Oudemans (Acarina: Erythraeidae). - Austr. J. Zool. 14: 687-819.

Southcott, R. V. 1989: Balaustiinae larva (Acarina: Erythraeidae) of a new genus from Iceland. - Ent. Scand. 20: 173-177.

Southcott, R. V. 1991: A further revision of Charletonia
(Acarina: Erythraeidae) based on larvae, protonymphs and deutonymphs. - Invert. Taxon. 5: 61131.

Southcott, R.V. 1992: Revision of the larvae of Leptus Latreille (Acarina: Erythraeidae) of Europe and North America, with descriptions of post-larval instars. Zool. J. Linn. Soc. 105: 1-153.

Thor, S. 1900: Første undersøgelse af Norges Trombidiidae. - Christiania 2: 1-18.

Welbourn, W. C. \& Young, O. P. 1987: New genus and species of Erythraeinae (Acari: Erythraeidae) from Mississippi with a key to the genera of North American Erythraeidae. -Annals of the Entomological Society of America 80: 230-242.

Zhang, Z.-Q. \& Goldarazena, A. 1996: Abrolophus and Grandjeanella larvae (Acari: Erythraeidae) ectoparasitic on thrips (Thysanoptera: Thripidae). - Systematic and Applied Acarology 1: 127-144. 